\title{
Population Growth and Economic Development in Pakistan
}

\author{
Mohammad Afzal* \\ Department of Economics, Gomal University, D.I. Khan 29090-Pakistan
}

\begin{abstract}
There is divergence of opinion regarding the consequences of population growth for economic development. Some view rapid population growth as a real problem while others assert that it is not a matter of grave concern. Crossnational evidence on the relationship between population growth and economic growth is inconsistent because the underlying parameters and assumptions vary across countries. Country-specific studies are more useful for illuminating unique features of a country. In this article, I examine Pakistan's case of population growth and economic development. Between 1950- 2001, Pakistan's population increased 430 percent. Multivariate analyses of 1981 to 2005 data from the Pakistan Economic Survey and from the International Financial Statistics yearbooks found significant and negative relationship between population growth and measures of economic advancement. These results demonstrate that rapid population growth is a real problem in Pakistan because it contributes to lower investment growth and diminishes the savings rate. Today foreign investment and export promotion have only a small impact on Pakistan's economic growth. Owing to its rapid population growth, Pakistan has among the world's highest dependency ratios. Policy makers can address these serious economic consequences of rapid population growth by investing in family planning services. Development of independent media and liberal education in educational institutions will in time also help by encouraging a smaller family size ideal.
\end{abstract}

Key Words: Population growth, Economic development, Pakistan.

\section{INTRODUCTION}

Population problem lies at the heart of Pakistan's social, economic and political problems. At the time of independence, Pakistan (united Pakistan that included former East Pakistan now Bangladesh) was the $13^{\text {th }}$ most populous country in the world with a population of 32.5 million but in 1996 it was seventh with a population of 140 million. Today Pakistan is the $6^{\text {th }}$ most populous country in the world with a population of 162 million. In 2050 its rank would be $5^{\text {th }}$ far exceeding the Bangladesh whose rank in 2005 is 7 (Table $\mathbf{1}$ ). United States and Indonesia will retain their ranks. Pakistan's population problem is distressing given its momentum and structure.

Table 2 provides a bird's eye view of the important demographic indicators comparing Pakistan's population profile with the Asian countries. Pakistan's position vis-à-vis Asian countries is not agreeable and adequate. Pakistan has the highest birth as well as total fertility rate among the Asian countries. This is alarming and requires immediate and immense attention and action.

Pakistan's population has grown at an average rate of 3\% per annum since 1951 until mid 1980s but it slowed to an average rate of $2.6 \%$ per annum during 1986-2000 and since 2001 it is growing at an average rate of almost $2 \%$ per annum. Had Pakistan's population grown at $2 \%$ since 1960, Pakistan's per capita income would have been Rs. 64366 as against Rs. 43748. During the five decades 1950- 2001,

*Address correspondence to this author at the Department of Economics, Gomal University, D.I.Khan 29090-Pakistan; Tel: (092)-(0966)-(731974); Fax: (092)-(0966)-(9280100); E-mail: profafzal@gmail.com
Pakistan's population has increased 4.3 times, whereas the population of South Korea increased only 2.4 times. Over the same period per capita income in Pakistan increased by only five times from $\$ 79$ in 1950 to $\$ 503$ in 2001, whereas in South Korea it increased by 129 times from $\$ 82$ in 1950 to $\$ 10550$ in 2001 [1].

Pakistan's population growth rate is now highest in Asia at $2.8 \%$. In 1947, a million people were added every year or so but today we are adding a million every three months. No conceivable development plan can sustain such a rate of population growth [3]. This evidence makes obvious the nature and severity of population problem. Since 1960s different governments have made serious efforts to check the unbridled population growth but the efforts have not succeeded. Because the common man has developed a phobia of practicing birth control mainly due to social reasons and cultural factors [4].

In absolute numbers almost 128 millions persons have been added during the last 58 years (1951-2008). The population density has increased four times from 42.5 persons per square kilometer in 1951 to 203 persons per square kilometer today. Rural-urban migration has swelled over the years due to push and pull factors and the urban population has increased from 6 million in 1951 to 57 million in 2008. This situation has exerted an enormous pressure on the supply of infrastructure like housing, transportation, electricity, water, sewerage, health and educational faculties [1]. Furthermore:

a) Sex ratio has declined over the years. It declined from 115 in 1972 to 111 in 1981 and to 107 in 1995 implying that the frequency of females has followed an increasing trend. This is distressing and painful 
Table 1. The World's 10 Largest Countries in Population

\begin{tabular}{|c|c|c|c|c|c|}
\hline \multicolumn{3}{|c|}{2005} & \multicolumn{3}{|c|}{2050} \\
\hline 2 & India & 1104 & 2 & China & 1437 \\
\hline 3 & USA & 296 & 3 & USA & 420 \\
\hline 5 & Brazil & 184 & 5 & Pakistan & 295 \\
\hline 6 & Pakistan & 162 & 6 & Brazil & 260 \\
\hline 7 & Bangladesh & 144 & 7 & Nigeria & 258 \\
\hline
\end{tabular}

Source [2]

Table 2. Demographic Indicators- Pakistan and Asian Countries

\begin{tabular}{|c|c|c|c|c|c|c|c|c|c|c|}
\hline Country & $\begin{array}{c}\text { Population } \\
\text { (Millions) } \\
\text { Mid-2005 }\end{array}$ & $\begin{array}{c}\text { Projected } \\
\text { Population } \\
\text { (Millions) } \\
2025\end{array}$ & $\begin{array}{c}\text { Births } \\
\text { per } \\
1000 \\
\text { pop }\end{array}$ & $\begin{array}{l}\text { Deaths } \\
\text { per } \\
1000 \\
\text { pop }\end{array}$ & $\begin{array}{c}\text { Infant } \\
\text { Mortality } \\
\text { Rate }\end{array}$ & $\begin{array}{c}\text { Life } \\
\text { Expec- } \\
\text { tancy at } \\
\text { Birth }\end{array}$ & $\begin{array}{c}\text { Total } \\
\text { Fertility } \\
\text { Rate }\end{array}$ & $\begin{array}{c}\text { \% Population } \\
\text { Below } 15 \\
\text { Years }\end{array}$ & $\begin{array}{c}\text { \%Population } \\
\text { Living Below } \\
\text { US \$2 per } \\
\text { Day }\end{array}$ & Income* \\
\hline Pakistan & 162.4 & 228.8 & 34 & 10 & 85 & 62 & 4.8 & 42 & 66 & 21601 \\
\hline India & 1103.6 & 1363.0 & 25 & 8 & 60 & 62 & 3.0 & 36 & 81 & 3100 \\
\hline Bangladesh & 144.2 & 190.0 & 27 & 8 & 65 & 61 & 3.0 & 35 & 83 & 1980 \\
\hline Indonesia & 221.9 & 275.4 & 22 & 16 & 46 & 68 & 2.6 & 30 & 52 & 3460 \\
\hline Philippines & 50.5 & 59.0 & 22 & 10 & 75 & 60 & 2.7 & 29 & - & - \\
\hline Japan & 127.7 & 121.1 & 9 & 8 & 2.8 & 82 & 1.3 & 14 & - & 30,040 \\
\hline
\end{tabular}

Income $=2004$ gross national income (GNI) PPP per capita (US \$) Source [2]

and is expected to fall further that will intensify social, psychological and economic problems for parents as well as females. There seems no solution to this agonizing problem in the short-run. Polygamy will make the confusion worse confounded. It is extremely difficult to adopt the western social system and values. Improvement in operation and implementation of the family planning program, increase in female literacy rate and enhancement of women social status appear to be an agreeable solution.

b) Rapid population growth in Pakistan has been alarming. Pakistan though ranked $6^{\text {th }}$ in size adds more than twice as many peoples to the absolute growth of world population than USA which ranks third. This situation has created insurmountable and complicated social, economic and political problems that have negative impact on the macroeconomic stability of the economy. Ethnic-strife and deteriorating law and order situation, heartbreaking problems of housing, expensive educational and health facilities, traffic density and congestion, frequent and fatal accidents have made the common man life miserable and unsustainable. These problems will aggravate if the population momentum continues.

c) These factors have collectively contributed to escalating cost of living that breeds macroeconomic instability on one hand and on the other hand, rising 
absolute and relative poverty and worsening income inequalities are the direct as well as indirect result of the aforesaid factors. Thus rapid population growth is the bone of contention as well as crux of the problems. Socio-economic conditions would be better off if population were to grow slowly that would have also resulted in a better social and economic condition.

d) Agriculture is the mainstay of Pakistan's economy. The arable land and almost all crops in Pakistan rely on irrigation. Supplies of both arable land and fresh water are unlikely to increase, calling into question Pakistan's ability to feed itself. Population pressures are threatening arable land, forests and water resources. The size of arable land holdings has decreased due to population growth, inadequate arable land reforms and inheritance patterns. Before the middle of this century, Pakistan is projected to face a scarcity of arable land with even less arable land available per person than in China. Limited renewable fresh water supplies may be the biggest obstacle to increasing Pakistan's food supply [5].

\section{POPULATION GROWTH AND ECONOMIC DEVELOPMENT}

For many years development economists and social scientists have debated the seriousness of the consequences of rapid population growth. Those who are of the view that rapid population growth is not a real problem have offered three arguments: (a) Population growth is not a problem but there are other issues. (b) Population growth reduction is a conspiracy of the capitalists' countries to keep developing countries in their dependence (c) For many developing countries population growth is desirable.

\section{$1^{\text {st }}$ Argument: Population Growth is not a Problem}

Underdevelopment, and not population growth is the real problem. As long as majority of the people in the developing countries remain poor, uneducated and physically weak, large family will constitute the only real source of social security. Population control programs are not expected to succeed when there is no motivation for the poor families to limit the family size. Population can only be an economic problem relative to the supply of natural and material resources. Developed countries with less than one-quarter of the world population consume $80 \%$ of the world resources. The higher fertility of the developing countries is the result of "over-consumption" of the world scarce resources by the rich countries. The average North American or European consumer consumes almost 16 times as much of the world food, energy and material resources as his or her counterpart in the developing countries. Thus the addition of another child in the developed countries consumes as much as the 16 children consume in the developing countries. The developed countries instead of asking the developing countries to check their population growth should reduce their unwarranted consumption standards.

Moreover, population distribution is causing the population problem. Some regions are under-populated (e.g. Balochistan province in Pakistan, few regions in Brazil and parts of sub-Saharan Africa) while other are over-populated (met- ropolitan cities in Pakistan Karachi, Lahore and Faisalabad or in other developing countries) due to concentration of employment opportunities and rural-urban migration, resulting from lopsided land and other productive resources distribution. Therefore, instead of checking population growth, government should discourage rural-urban migration so that more natural spatial distribution of population gains ground.

Another important factor responsible for population growth is the natural outcome of the women's lack of economic opportunity. Women often bear the disproportionate burdens of poverty, poor education, lack of jobs and limited social mobility. Their inferior status and roles are manifested in their high fertility. If women's roles and status, their education and economic well-being are improved, this will lead to smaller families and lower population growth.

\section{$2^{\text {nd }}$ Argument: Capitalists' Countries Conspiracy}

The second pro-population growth argument is closely related to the neocolonial dependence model which is an indirect outgrowth of Marxist thinking. It has been argued that overanxiety of the developed countries about the population growth of the poor countries is an attempt to arrest the development of the developing countries in order to maintain international status quo that serves their self-interest. The developed countries also passed through a period of considerable population growth that accelerated their own development. But the developed courtiers are pressurizing the poor countries to adopt aggressive population control programs to restrict their population growth that supports the second line of the pro-population growth argument.

\section{$3^{\text {rd }}$ Argument: Population Growth is Desirable}

The third argument is a conventional argument. According to this argument, though rapid population growth results in additional demand for food, clothing, shelter, social services like education and health, and growing employment opportunities, the high population growth also adds to the labor supply that can be used for productive purposes and provides potential for large markets for goods and services and therefore large population affords a big opportunity to benefit from demographic dividend which can add to growth [1]. Neoclassical economists argue that free markets will always adjust to the problems created by population growth. It has also been argued that many rural areas in the developing countries are under populated due to scarcity of labor despite the availability of arable land and large increases in agriculture output will occur if labor were available to cultivate it. Many regions in Africa, Latin America and some parts of Asia have this situation. Furthermore, there are many ethnic, racial and religious groups in developing countries that are enamored of large families, and high population growth is considered desirable for political and military power. The last argument does not carry a significant weight because the peculiar situation obtaining in few regions does not warrant high population growth.

These arguments carry some weight but this need to be weighed against the counter arguments of those who believe that rapid population growth is a real problem for LDCs (less developed countries). One view is that all of the world's economic and social problems result from excessive popula- 
tion growth. The advocates maintain that population control or even decline is the most urgent task of the LDCs even if it requires severe and coercive measures like compulsory sterilization in India and Bangladesh.

Economists argue based on population-poverty cycle theory that rapid population growth gives way to negative economic consequences and this should be a real concern for the developing countries because population growth retards prospects of a better life for the already born by reducing savings rate at the household and national levels.

Empirical evidence divides the negative consequences of population growth into seven categories. Rapid population growth lowers per capita income growth in most LDCs. The poor bears the brunt of the negative effects of population growth. They become landless, face loss in jobs, and the government reduction of expenditure on education and health. It is generally agreed that large family size and low incomes limit the opportunities of parents to educate all their children. High fertility harms the health of mothers and children. Rapid population growth generates food security problem and contributes to environmental degradation in the form of deforestation, soil erosion, unsafe water, air pollution and urban congestion. Rapid population growth is the major factor causing increasing international migration both legal and illegal. ${ }^{1}$

The Malthusian population trap is the well-known theory of the relationship between population growth and economic development. According to this theory, human population grows geometrically while means of subsistence grow arithmetically being subject to the law of diminishing returns. This theory has convinced many development economists, demographers and policy makers that rapid population growth retards economic development by tightening job markets, generating underemployment and discouraging labor force mobility across sectors [7]. Malthus Theory is based on a number of simplistic assumptions and hypotheses that do not stand the test of empirical verification [6].

In recent years, economists have attempted to apply the theory of consumer behavior to explain family size decisions in which children have been treated as consumption (and in LDCs investment) good, so that family's demand for children relative to other goods becomes a rational economic response. The economic theory of fertility has gained strong support in diverse developing countries [8-10].

[11] have put forward a theory emphasizing family economics and capital formation. According to this theory rapid population growth forces families to consume what otherwise would be savings, adversely affecting national savings rates and thus capital formation and investment rates as well. Though the cross-countries evidence for a negative relationship between population growth and per capita economic growth is inconsistent, some studies find the expected relationship; others find no relationship [12]. Studies done in the context of Pakistan's experience ${ }^{2}$ have not examined the

\footnotetext{
${ }^{1}$ For detail see [6]

${ }^{2}$ There are numerous studies on different aspects of Pakistan's population. See, for example, 1980s and 1990s issues of The Pakistan Development Review and other publications of The Pakistan Institute of Development Economics (PIDE) Islamabad.
}

impact of population growth on the economic development of Pakistan. The problem of population growth is not simply a problem of numbers but has welfare implications. If development means improvement in living standard, then how does the present population situation in Pakistan affect the goals of development not only for present generations but also for future generations?

Since cross-countries studies differ on the relationship between population growth and development, given the present population situation in Pakistan, we examine empirically the relationship between population growth and economic development in Pakistan.

\section{METHODOLOGY}

[12] used economic growth rates of 75 developing countries and regressed annual average percentage change in real GDP on demographic and macroeconomic variables for the period 1965 to 1990 . They find that an increase in the child population hinders economic progress, while an increase in adult population fosters economic development. Thus their major conclusion is that the "influence of population growth on economic growth depends on the age of the population segment that is growing". Their study suffers from many methodological problems besides their principal conclusion is debatable. They used two models that differ only in their specification of population growth as mentioned by the authors. Their study has the following problems.

1. It is a cross-section study covering 75 countries. The cross section studies assume that parameters are similar across countries. This is an unrealistic assumption and therefore, these studies have not succeeded in providing a uniform support on population and economic growth relationship. The conclusions of these studies are doubtful and policy implications are hardly reliable.

2. It is dangerous and inadequate to generalize too much about developing countries, despite sharing common goals and problems because of different geography, resource endowment, historical and colonial background, cultural, social and political systems. To aggregate the experience of all developing countries is to attribute common elements that may not have any real existence.

3. Using population growth and labor force growth in the same equation turn out to be highly collinear. Their model suffers from multicollinearity casting doubts on the results.

4. Regressing annual percentage change in real GDP per capita on real GDP per capita for single year as well as percentage change in population below and above 15 years for a single country Pakistan, we got near singular matrix for both variables.

5. Using private direct investment (1965-1978 average) is hardly tenable for all developing countries as it is 1980s phenomenon particularly in the context of Pakistan's experience. "Since late 1980s foreign investment both direct and portfolio, has assumed immense importance as a source of foreign capital to developing countries [13]. Therefore, their choice of vari- 
Table 3. OLS Results

\begin{tabular}{|c|c|c|c|c|}
\hline \multicolumn{5}{|c|}{$\begin{array}{c}\text { Dependent Variable: } Y_{\mathrm{g}} \\
\text { Method: Least Squares } \\
\text { Sample : 1981-2005 }\end{array}$} \\
\hline Variable & Coefficient & Std. Error & t-Statistic & Prob. \\
\hline $\mathrm{C}$ & -4.15 & 16.42 & -0.25 & 0.80 \\
\hline $\mathrm{POP}_{g}$ & -4.45 & 1.72 & -2.59 & 0.02 \\
\hline $\operatorname{Inv}_{\mathrm{g}}$ & 0.43 & 0.08 & 5.28 & 0.000 \\
\hline $\mathrm{FI}_{\mathrm{g}}$ & 0.004 & 0.01 & 0.32 & 0.75 \\
\hline $\mathrm{X}_{\mathrm{g}}$ & 0.101 & 0.09 & 1.05 & 0.31 \\
\hline $\mathrm{C}_{\mathrm{a}}$ & 0.22 & 0.22 & 1.02 & 0.32 \\
\hline $\mathrm{R}^{2}$ & 0.64 & $\mathrm{JB}$ & \multicolumn{2}{|c|}{$\mathrm{F}=1.53(0.46)$} \\
\hline F-statistic & 6.90 & $\mathrm{SC}(1)$ & \multicolumn{2}{|c|}{$\mathrm{F}=0.38(0.55)$} \\
\hline Prob(F-statistic) & 0.001 & HS & \multicolumn{2}{|c|}{$\mathrm{F}=1.50(0.23)$} \\
\hline DW stat & 1.92 & $\mathrm{FF}(1)$ & \multicolumn{2}{|c|}{$\mathrm{F}=2.83(0.08)^{* *}$} \\
\hline
\end{tabular}

* Figures within parentheses for F-statistic are p-values

ables, methodology and conclusions suffer from serious limitations due to aforementioned reasons. Because of the availability of time series data countryspecific studies are better and useful as they throw light on the distinguishing features of a country.

We, therefore, use the following simple model expressing the relationship between real GDP growth a proxy for economic growth and important macroeconomic variables having bearing on the economic growth. We presume that the economic growth is greatly influenced by the population growth; growth of exports, domestic and foreign investment, and market size represented by private consumption expenditure as percentage of GDP.

In equation form we have

$\mathrm{Y}_{\mathrm{g}}=\beta_{0}+\beta_{1} \mathrm{POP}_{\mathrm{g}}+\beta_{2} \operatorname{Inv}_{\mathrm{g}}+\beta_{3} \mathrm{FI}_{\mathrm{g}}+\beta_{4} \mathrm{EX}_{\mathrm{g}}+\beta_{5} \mathrm{C}_{\mathrm{a}}+\mu$

Where

$\mathrm{Y}_{\mathrm{g}}=$ real GDP growth

$\mathrm{POP}_{\mathrm{g}}=$ population growth

$\operatorname{Inv}_{\mathrm{g}}=$ real gross domestic investment growth

$\mathrm{FI}_{\mathrm{g}}=$ real foreign investment growth

$\mathrm{EX}_{\mathrm{g}}=$ exports growth

$\mathrm{C}_{\mathrm{a}}=$ private consumption as percentage of GDP

$\mu=$ White noise error term

The expected sign of all coefficients is positive except population growth. Except foreign direct investment, data on other variables were obtained from [1] government of Pakistan (GOP) Economic Survey (various Issues) while data on foreign direct investment were collected from IMF, Interna- tional Financial Statistics yearbooks [14]. The period of the study is from 1981 to 2005 .

\section{EMPIRICAL RESULTS}

The estimation results of equation 1 have been shown in Table 3. The coefficients have expected and correct signs. This equation was subjected to specification and diagnostic tests [Breusch-Godfrey LM (SC), White Heteroscedasticity (HS), the Jarque and Bera (JB) statistic and Ramsey RESET (FF)]. ${ }^{3}$

The Jarque - Bera (JB) statistic did not reject the hypothesis that the residuals originate from a normal distribution. For residual autocorrelation Breusch-Godfrey LM (SC) test does not reject the hypothesis of no autocorrelation. $\mathrm{R}^{2}$ and DW are satisfactory. Heteroscedasticity is not a problem because of insignificant F-statistic (HS). For Ramsey RESET Test (FF) F- statistic is significant at $10 \%$ level of significance suggesting slight misspecification. But this is not of great significance because White test, which is also used as a specification test is not significant implying that the underlying equation is not, missspecified. F statistic is highly significant showing the joint significance of all right- hand variables. The statistical appropriateness of the equation is supported by all the diagnostic tests.

The coefficient for population growth is negative and significantly different from zero meaning that population

\footnotetext{
${ }^{3}$ It might be pointed out that since we are using time series data, it is quite likely that the underlying variables are nonsatationary and therefore, variables are examined for unit roots, cointegration and error correction; the use of which has become very frequent in the more recent research of economics. Furthermore, time series econometrics techniques primarily deal with large sample. Our sample is not large enough to subject our variables to the aforesaid techniques. Furthermore, $\mathrm{R}^{2}$ is not in excess of 0.90 suggesting spurious regression and DW is also reasonable.
} 
growth adversely affects the economic growth. This does not support the view that population growth is not a real problem. For a country like Pakistan, rapid population growth is indeed a real and important problem because Pakistan has the highest total fertility in the Asian countries (Table 2), besides the other negative consequences of rapid population growth mentioned above. High population growth has become an important limiting factor for achieving the overall development goals. It is highly desirable this rampant population growth is checked to release the pressure on the existing infrastructure if the gains of growth are not eaten up by the high population growth. Pakistan's situation cannot be compared with the developed and sparsely populated countries (e.g. Canada) situations as the two are divergent. Manpower export of the exploding population is not possible because already many millions Pakistanis are working abroad notably in oil-rich Middle Eastern countries and the remittances are a significant source of foreign exchange earnings and form an important part of the current account balance.

Resources that could be used for productive purposes are diverted to satisfy the consumption needs that have adversely affected the national saving rate. Pakistan had to seek external financial assistance that has burdened the country with heavy debt whose service over years has become unpalatable. Pakistan has one of the lowest savings rate in Asia. According to the Asian Development Outlook 2002, the domestic saving in Pakistan in 2002 was $14.6 \%$ of GDP as compared to $23.6 \%$ in India, $20.7 \%$ in Bangladesh, $23 \%$ in Indonesia and 38\% in China. Investment growth is positive and highly significant implying that growth in investment will significantly contribute to economic growth, which in turn depends on high saving rate. High rates of domestic saving are important because savings provide most of the funds for investment. Empirical evidence for East Asia shows that there is a strong positive correlation between domestic saving and investment rates [15].

Coefficients for foreign investment and exports are positive though not significant. Foreign investment and export promotion are more recent phenomenon in Pakistan. Export promotion policies were adopted in early 1990s and this policy has been moderately successful [16]. Now foreign aid is not available at concessional terms after the end of cold war. That is why various governments have offered diverse incentives to attract foreign investment. [1] stated "substantial benefits in the shape of capital, advance technology, new managerial and technical skills, marketing expertise, employment generation and linkages with the outside world" are the potential advantages of foreign investment. Pakistan has succeeded in attracting $\$ 3.02$ in foreign direct investment (FDI) in 2005-06- the highest ever in the country's history, against $\$ 0.89$ billion in the same period last year. Significant improvement in country's overall macroeconomic environment and up-gradation of Pakistan credit rating have helped attract large inflows of FDI [1]. ${ }^{4}$

\footnotetext{
${ }^{4}$ It might be pointed out that labor a crucial input in the production function has been ignored. Labor was dropped as an explanatory variable because taking into account the fact that labor (particularly unskilled) is generally abundant in most developing countries including Pakistan. Instead of using the growth of labor as factor input, we experimented with growth of expen-
}

Private consumption as percentage of GDP (Ca) is also positive. Consumption being a positive function of income contributes positively to economic growth, but being not significant implies that its impact is not noteworthy. Therefore, in the aggregate demand management policies, exclusive reliance on private consumption is less likely to generate desired results. Compared to the Asian countries (Table 2), Pakistan has the highest dependent population below 15 years. This large proportion of children hinders economic growth because they are non-productive members of the society and must be supported financially by the active labor force. This increases marginal propensity to consume. Saving rate is reduced that adversely affects the investment environment. Living standards fall and in the final analysis productive efficiency of the working force is badly affected.

\section{POPULATION, ENVIRONMENT AND POVERTY}

Like most developing countries, Pakistan faces serious environmental problems. Rapid population growth and impressive GDP growth have put immense pressure on the country's natural resource base and have significantly increased levels of pollution. Rapid expansion in industrial production and urbanization has led to increased levels of industrial waste, water pollution, solid waste, and vehicle emissions that have resulted in serious health problems in many areas of the country. [17] has attempted to value environmental costs in Pakistan and has put the estimate of environmental damage at $\$ 1$ billion to $\$ 2.1$ billion per year, or 2.6 to 5.0 percent of GDP in 1992 values.

There is a close association between rapid population growth and poverty. With stagnant or deteriorating employment opportunities, a persistent increase in population would result in increasing relative and absolute poverty. More recent evidence on the incidence of poverty indicates that poverty that declined in 1970s and 1980s increased in 1990s that have adversely affected the poor families demand for education and the health and housing conditions have also deteriorated. ${ }^{5}$ The issue of poverty in Pakistan has its significance for sustainable development. Long- run development is not possible without protecting the rights of the vulnerable groups and the participation of the entire population in the development process [see 18].

The incidence of poverty increased in 1990s mainly because of dismal economic growth. Growth has always helped in poverty reduction. The dominant effect of growth has been of poverty reduction [19]. Poverty can be taken care of if the economy succeeds in achieving a respectable economic growth of more than $6 \%$. Diverse policy options could be used to take care of poverty incidence. Policies are adopted that reduce the concentrated control of assets and unequal access to education and income- earning opportunities. Since

diture on health and education as proxy for human resource development (HRD). It is the human resources of a nation that ultimately determine the character and pace of its economic and social development because education makes not only efficient workers but also good citizens who contribute to socio-economic development in a balanced way. Growth of HRD was negative for some years and we got statistically unreliable results, so it was dropped.

A large number of studies on poverty in Pakistan using diverse approaches have been done. See 1980s, 1990s and 2000s issues of The Pakistan Development Review for poverty scenario in Pakistan. 
rapid economic growth and population growth are incompatible, population growth must be reduced.

\section{CONCLUSIONS}

Since the publication of Thomas Malthus Essay on the Principle of Population in 1798 development economists and policy makers have devoted a good deal of effort to address the problem of population growth. There is divergence of opinion regarding the desirability of population growth. Some view rapid population growth a real problem while others assert that it is not a matter of grave concern. Crosscountries evidence on the population growth and economic growth relationship is not consistent and uniform. These studies are based on the unrealistic assumption that parameters are similar across countries and aggregating the experience of all developing countries is to attribute common elements that may not have any real existence. Availability of time series data has made the country-specific studies desirable and useful as they throw light on the distinguishing features of a country.

Rapid population growth has assumed alarming proportions in Pakistan. It was the $13^{\text {th }}$ most populous country with a population of 32.5 million in 1947 ; today Pakistan is the $6^{\text {th }}$ most populous country in the world with a population of 162 million. Pakistan's population problem is distressing given its momentum and structure. Pakistan has the highest birth as well as total fertility rate among the Asian countries. During the five decades 1950-2001, Pakistan's population has increased 430 percent. Government of Pakistan policies and programs to contain the uninhibited population growth has not made an enviable success. The common man does not realize the negative economic consequences of rapid population growth due to social reasons and cultural factors.

We estimated a simple model to examine empirically the relationship between population growth and economic development in Pakistan. Specification and diagnostic tests supported the statistical appropriateness of the model. Highly significant and negative coefficient of population growth demonstrates that population growth is a real problem in Pakistan because it adversely affects the economic growth. Resources instead of being directed to productive channels are consumed by the exploding population.

Positive and highly significant investment coefficient implies that investment growth will considerably contribute to economic growth which in turn depends on high saving rate. Foreign investment and export promotion are expected to have benign impact on economic growth of Pakistan. However, foreign investment has to be carried out cautiously and vigilantly. Without investigating in depth the positive and negative aspects of foreign investment, it is most likely that the uncritical acceptance of foreign investment may turn disagreeable like foreign aid. Pakistan has the highest de- pendent population that hinders economic growth because this population encompasses non-productive members of the society.

Poverty can be taken care of if the economy succeeds in achieving a respectable economic growth of more than $6 \%$. Plans to reduce population growth over the years do not seem to have succeeded. Therefore, population growth has become a critical issue that discourages economic development and must be addressed seriously and squarely in order that the country has respectable economic growth. Provision of scientific and liberal education in educational institutions and independent media can make the people think independently and rationally that will help encourage a smaller family size ideal.

\section{REFERENCES}

[1] Economic Survey (various issues), Islamabad, Ministry of Finance, Government of Pakistan. Economic Advisor Wing.

[2] Population Reference Bureau, World Population Data Sheet, New York, 2005.

[3] Sadik N, Social Change - the Essence of development, Pak Dev Rev 1997; 36: 315 -20.

[4] Mahmood N, Ali SM, Population planning in Pakistan: issues in implementation and its impact. Pak Dev Rev 1997; 36: 875-88.

[5] Rosen JE, Conly SR. Pakistan's population program: the challenges ahead 1995.

[6] Todaro MP, Stephen CS. Economic Development. 8th ed. Singapore; Pearson Education, 2004.

[7] Coale, Ansely J. Population trends and economic development, in world population and US policy: the choices ahead. J Menken Ed., New York: W.W. Norton; 1986.

[8] Birdsall N, Economic approaches to population growth. In Hollis B, Chenery T.N., Srinwasan, Eds. Handbook of Development Economics, vol.1, Amsterdam: North Holland; 1988.

[9] Dasgupta P. The Population problem: theory and evidence, J Eco Liter 1995; 33: 1879-1902.

[10] Dreze J, Murthi M, Guio AC. Mortality, fertility, and gender bias in India: a district level Analysis. Popul Dev Rev 1995; 21: 745-82.

[11] Coale A, Edgar J, Hoover M. Population growth and economic development in low income countries. Princeton, New Jersey: Princeton University Press; 1958.

[12] Crenshaw, Edward M, Ansari ZA, Christenson M. Population dynamics and economic development: age-specific population growth rates and economic growth in developing countries: 1965 to 1990. Am Soc Rev 1997; 62: 974-84.

[13] World development report . World Bank. Washington D.C.: Oxford University Press; 1991.

[14] IMF, International Financial Statistics (various issues), Washington D.C.

[15] Afzal M. Estimating saving and investment functions in Pakistan. Philip Rev Eco 2004; 41: 67-78.

[16] Afzal M. Causality between exports, world income and economic growth in Pakistan. Int Eco J 2006; 20: 63-77.

[17] Brandon C. Valuing environmental costs in Pakistan. The economy-wide impact of environmental degradation 1995, Background paper for Pakistan 2010 Report.Washington D.C., World Bank, Asia Technical Department 1995.

[18] Bhatti, Ali M, Haque R, Javed T, A sectoral analysis of poverty in Pakistan. Pak Dev Rev 1999; 38: 859-72.

[19] Ali SS, Tahir S. Dynamics of growth, poverty and inequality in Pakistan. Pak Dev Rev 1999; 38: 837-58.

Received: October 10, $2008 \quad$ Revised: December 19, 2008

Accepted: December 24, 2008

(C) Mohammad Afzal; Licensee Bentham Open.

This is an open access article licensed under the terms of the Creative Commons Attribution Non-Commercial License (http://creativecommons.org/licenses/by-nc/3.0/) which permits unrestricted, non-commercial use, distribution and reproduction in any medium, provided the work is properly cited. 